dr. sc. Boris Marjanović, v. pred. ${ }^{1}$

Marino Učeta, struč. spec. oec.

\title{
SEGMENTACIJA TRŽIŠTA VISOKOG OBRAZOVANJA
}

Stručni rad / Professional paper

UDK / UDC: 658.8.012.2:378

DOI: 10.51650/ezrvs.15.1-2.10

Primljeno / Received: 10/2/2021

Prihvaćeno / Accepted: 29/3/2021

Rad analizira pitanje identifikacije tržišnih segmenata na tržištu visokog obrazovanja. Segmentacija je bitan alat u postizanju konkurentske prednosti, posebice na zrelim i visoko konkurentnim tržištima poput tržišta visokog obrazovanja, i pogotovo u današnje doba kada su granice otvorene te je mobilnost studenata izrazito lako ostvariva i dostupna. Tržište je otvoreno i svaka svjetska visokoškolska institucija predstavlja ozbiljnog konkurenta institucijama u Republici Hrvatskoj. Ovim istraživanjem utvrđeno je postojanje 7 specifičnih tržišnih segmenata na tržištu visokog obrazovanja u Hrvatskoj, temeljenom na kriteriju segmentacije prema ponašanju, odnosno prema kriteriju koristi. $\mathrm{Na}$ osnovi utvrđenih kriterija hrvatske visokoškolske institucije mogu prilagoditi vlastitu obrazovnu uslugu s obzirom na specifičnosti ciljanih segmenata, čime mogu ostvariti prednost nad ostalim konkurentima na tržištu.

Ključne riječi: marketing visokog obrazovanja, usluga visokog obrazovanja, segmentacija tržišta prema koristi.

\section{Uvod}

Segmentacija tržišta predstavlja korak između masovnog marketinga i individualiziranog pristupa prema potrošaču. Današnja tržišta preplavljena su kupovnim opcijama te potrošači imaju moć da biraju ono što će bolje ispuniti njihove potrebe. Segmentacijom tržišta nastoji se razumjeti na temelju čega potrošači u svakom segmentu biraju što kupiti, kako bi poduzeća mogla što bolje oblikovati vlastitu ponudu i postići prednost nad konkurentima. Visoko obrazovanje načelno se ne razlikuje od ostalih djelatnosti pa razumijevanje tržišta potencijalnih studenata može pomoći visokoškolskim institucijama da prilagode vlastitu ponudu prema potrebama potrošača u ciljanim segmentima i osiguraju željeni broj upisa na tržištu koje je visoko konkurentno.

Za potrebe segmentacije tržišta visokog obrazovanja provedeno je više istraživanja u nastojanju da se stekne jasnija slika potreba i preferencija budućih studenata. Sudarikov et al. (2019) ističu da unatoč primjeni marketinga od strane svjetskih visokoškolskih institucija,

1 Istarsko Veleučilište - Università Istriana di scienze applicate, e-mail: bmarjanovic@iv.hr 
segmentacija tržišta visokog obrazovanja nije kvalitetno utvrđena u literaturi. Stoga su autori predložili sljedeće parametre za potrebe segmentiranja tržišta: prestiž sveučilišta, niska cijena obrazovanja, niska razina poteškoća pri stjecanju znanja te mogućnost rada u inozemstvu. Kombinacijom različitih utjecaja navedenih čimbenika utvrđena su tri tržišna segmenta. Church i Gillingham (1988) predložili su pet dimenzija koristi za potrebe utvrđivanja tržišnih segmenata: razvoj osobnih vještina, osobni napredak, društvena očekivanja, učenje i istraživanje, te intelektualni razvoj. Različitim kombinacijama utjecaja navedenih koristi utvrđeno je šest osebujnih segmenata. Ladd et al. (2014) navode kako, primjerice, dob kao kriterij za segmentaciju ne može na adekvatan način predočiti razlike u preferencijama studenata prema visokom obrazovanju. Stoga je motivacija u odnosu na stjecanje očekivanih koristi nakon završenog odabranog studija uzeta kao temelj za analizu, čime je utvrđeno šest tržišnih segmenata. Schatzel et al. (2011) koristili su pak kombinaciju demografskih i psihografskih čimbenika za segmentaciju s posebnim osvrtom na namjeru ispitanika za povratak i nastavak studiranja, čime su utvrdili pet jedinstvenih segmenata.

Dosadašnja istraživanja ukazuju na različitost u pristupima segmentiranja tržišta visokog obrazovanja. Samim time čimbenici segmentacije značajno variraju i sukladno tome dobiva se jedna širina u različitosti samih rezultata.

\section{Marketing u visokom obrazovanju}

Obrazovanje je bitno utoliko što osposobljava čovjeka za život i suživot s ostalim članovima društva. Korak dalje u obrazovanju pojedinca je ono koje se stječe na višim stupnjevima poput tercijarnog obrazovanja ili visokog obrazovanja (Marjanović, 2017). Visoko obrazovanje je bilo koji oblik obrazovanja koji se pruža na postsekundarnim institucijama obrazovanja koje nakon završetka programa studija udjeljuju diplomu ili drugu visokoobrazovnu kvalifikaciju (Encyclopædia Britannica, 2009).

Marketing u visokom obrazovanju generalno se može razumjeti kao marketing koji se primjenjuje na obrazovnim institucijama poput sveučilišta, fakulteta i visokih škola. Marketing u visokom obrazovanju temelji se na osnovnim načelima marketinga koji su univerzalni. Marketing kao pojam stoga možemo sažeti kao zbir svih aktivnosti poduzetih od strane potrošača i ponuđača prilikom razmjene proizvoda za određenu novčanu vrijednost; potreba je temeljni pokretač razmjene, a potrošač centralna točka poslovanja svakog ponuđača. Temeljni pojmovi marketinga u visokom obrazovanju uključuju potrošača s jedne strane i ponuđača s druge strane, te potrebu kao pokretača razmjene. U ovom konkretnom slučaju potrošača predstavlja potencijalni student, ponuđač je institucija visokog obrazovanja, a odraz potrebe predstavlja usluga visokog obrazovanja (Marjanović, 2017).

Međutim, postavlja se pitanje zašto je potrebno razmatrati marketing u visokom obrazovanju? Maringe i Gibbs (2009) argumentiraju opravdanost primjene marketinga u visokom obrazovanju na temelju četiriju sila:

- Omasovljenje visokog obrazovanja: dostupnost visokog obrazovanja je sve veća kao reakcija na povećanje potražnje za visokim obrazovanjem;

- Ekspanzija i diversifikacija: sve šire mogućnosti obrazovanja uslijed efekta omasovljenja visokog obrazovanja; 
- Rast heterogenosti u visokom obrazovanju: očituje se u prirodi i sastavu studenskih tijela na kampusima širom svijeta, u širem rasponu smjerova visokog obrazovanja i iznad svega u akademskom sadržaju i mehanizmima isporuke;

- Rast konkurencije u visokom obrazovanju: predstavlja odraz svjesnih vladinih politika različitih zemalja uslijed promjena u globalnoj ekonomiji, kao odgovor na ideologiju tržišne moći, primjerice, zakonski namet stavljen na sveučilišta za prihvaćanje marketinga kao ključnog strateškog aspekta institucijskog razvoja.

Zaključno, može se istaknuti da marketing treba promatrati kao proces izgradnje odnosa koji se temelji na povjerenju, a čiji je cilj osposobljavanje korisnika visokog obrazovanja. Marketing predstavlja svojevrstan oblik razmjene i isporuke vrijednosti te je nužno da obrazovanje usvoji marketinške principe kao sastavnice vlastitog razvoja (Maringe i Gibbs, 2009).

\section{Usluga visokog obrazovanja}

Visoko obrazovanje je uslužna djelatnost i kao takva nudi na tržištu uslugu. Usluga se razlikuje od proizvoda u suštinskom smislu ili prirodi, iako i proizvod i usluga služe istoj svrsi, a to je zadovoljenje potrebe potrošača. Usluga se razlikuje od proizvoda na temelju četiriju prepoznatljivih karakteristika: neopipljivost, nedjeljivost, heterogenost i neuskladištivost. To vrijedi i za uslugu visokog obrazovanja, koju je teško definirati zbog njezine specifične prirode (Mazzarol, 1998), jer za razliku od fizičkih proizvoda, usluga se ne može vidjeti ni opipati prije no što se kupi (Kotler i Keller, 2006).

Slika 1 prikazuje usporednu skalu dominantnosti entiteta i njihovog utjecaja. Proizvodi i usluge prikazani su na dva ekstremiteta skale, što ukazuje na njihovu suštinsku dominantnost. Hibridni entiteti nalaze se u centru i suštinski predstavljaju ujednačenu kombinaciju proizvoda i usluga (Shostack, 1982). Iz prikaza je vidljivo da obrazovanje spada u kategoriju čiste usluge s visokim stupnjem neopipljivosti. 


\section{Slika 1. Skala dominantnosti entiteta}

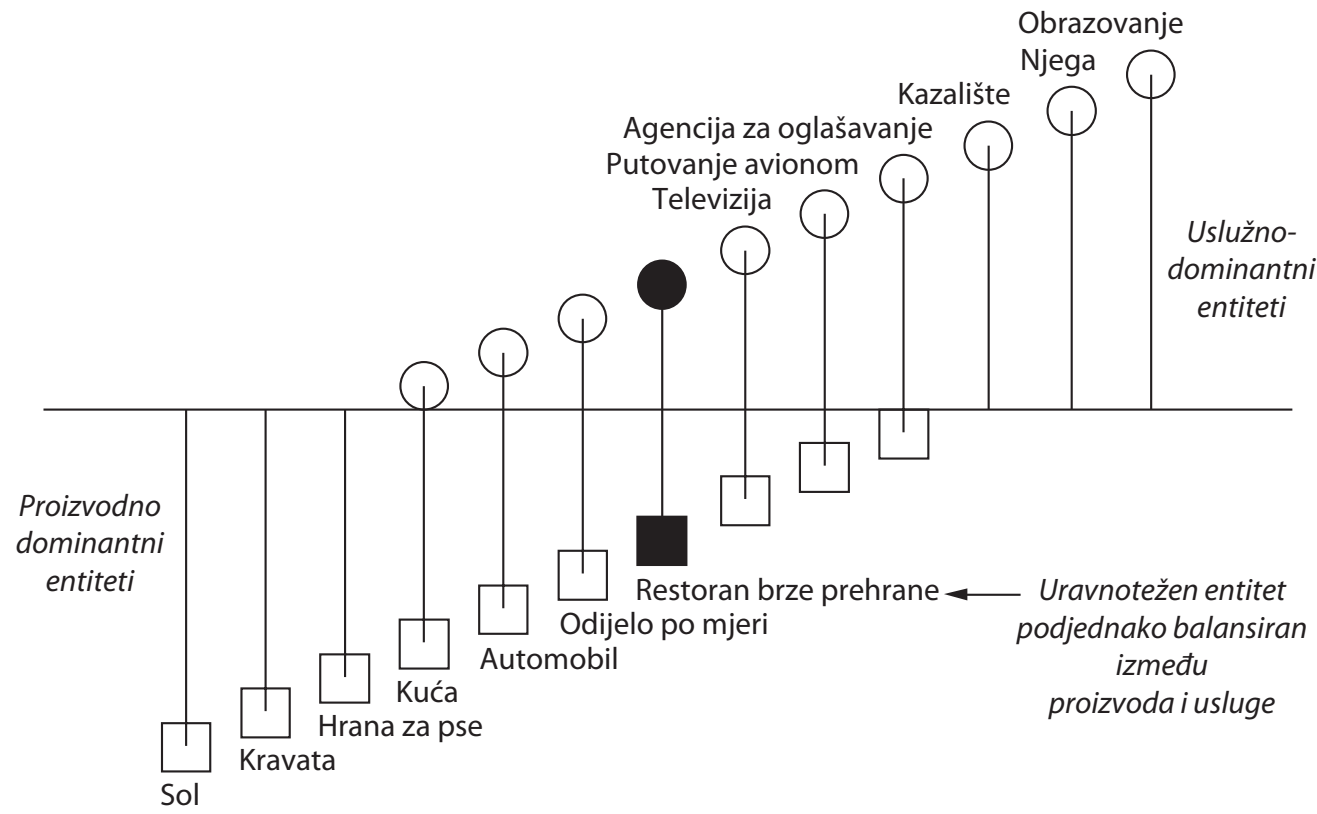

Izvor: Shostack, L. G. (1982.), How to design a service, European Journal of Marketing, 16(1), str. 52.

Postoje razne definicije usluge visokog obrazovanja, ali za potrebe sažetosti u nastavku će biti navedene dvije, i to s općeg i marketinškog aspekta. Usluga visokog obrazovanja je profesionalna usluga i spada u kategoriju čiste usluge. Karakterizirana je velikim stupnjem interpersonalnog kontakta, kompleksnosti, divergencije (različitosti) i prilagodbe, više nego bilo koji drugi oblik usluge prisutne na tržištu (Patterson et al., 1998). S marketinškog stajališta usluga visokog obrazovanja kompleksan je pojam koji predstavlja i proces distribucije znanja i proizvod kao sklop materijalnih i nematerijalnih elemenata koji čine nevidljivu cjelinu. Ona se valorizira kroz dva bitna elementa: kroz studente, kao elemente procesa kojima ugrađuje dodatnu vrijednost (znanje, vještine, kompetencije), odnosno njihovu uspješnost studiranja mjerenu ocjenama kao jedinim raspoloživim mjerilom, i kroz njihovu valorizaciju na tržištu rada (Leko Šimić i Štimac, 2013).

\section{Proces donošenja odluke i segmentacija tržišta}

Zašto se potencijalni studenti odlučuju za nastavak obrazovanja u visokom školstvu? Odgovor na to pitanje može se pronaći svakako u osobnoj motivaciji i koristima koje proizlaze iz stjecanja stupnja visokoškolskog obrazovanja. Ali motivacija je dakako značajan čimbenik utjecaja na proces odlučivanja potrošača i može se definirati kao unutarnji pokretač na djelovanje u cilju ispunjenja nezadovoljene potrebe (Assael, 1998). Motivacija može se sagledati s različitih teorijskih stajališta, a najpoznatije teorije motivacije su: Maslowljeva hijerarhija potreba, Herzbergova dvo-čimbenička teorija motivacije/higijene, McGregorova XY teorija, i McClellandova motivacijska teorija potreba (Pardee, 1990). 
Proces donošenja odluke u visokom obrazovanju može se definirati kao složen višefazni proces tijekom kojeg pojedinac razvija težnju za nastavkom formalnog obrazovanja nakon srednje škole, te potom odluku za pohađanje specifične visokoškolske institucije, bilo da je to sveučilište ili neka druga institucija stručnog usavršavanja (Hossler et al., 1989). Složenost procesa donošenja odluke u visokom obrazovanju može se razumjeti i sa stajališta potrebe ulaganja značajnih novčanih sredstava, vremena i truda za stjecanje visokoškolskog zvanja.

Za potrebe opisivanja složenog procesa donošenja odluke, Kotler i Keller (2006) navode višefazni model procesa donošenja odluke o kupnji. Potrošači u procesu kupnje prolaze kroz pet faza: spoznaja problema, potraga za informacijama, vrednovanje alternativa, odluka o kupnji i ponašanje nakon kupnje. U složenom donošenju odluke potrošači vrednuju marke na opsežan i detaljan način. Traži se veći broj informacija i vrednuje se više marki nego u bilo kojoj drugoj situaciji odluke (Assael, 1998). Slika 2 prikazuje model procesa donošenja odluke o kupnji kroz pet faza.

Slika 2. Petofazni model procesa donošenja odluke u kupnji

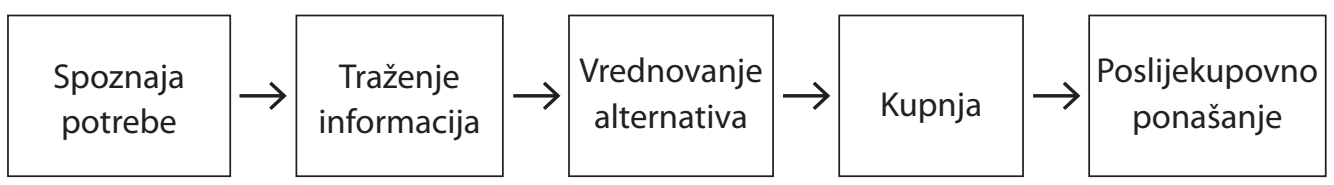

Izvor: Kotler, P., i Keller, K. L. (2006.). Marketing management. New Jersey: Prentice Hall, str. 191.

- Spoznaja problema: ukazuje na prepoznavanje potrebe ili problema koji potrošač želi riješiti, što će ga motivirati na akciju zadovoljavanja te potrebe.

- Potraga za informacijama: potrošač će se upustiti u traženje dodatnih informacija i mogućim alternativama koje mogu zadovoljiti njegovu potrebu.

- Vrednovanje alternativa: potrošač ulazi u fazu razmatranja mogućnosti zadovoljenja vlastite potrebe vrednovanjem ustanovljenih alternativnih rješenja.

- Odluka o kupnji: potrošač donosi konačnu odluku o odabiru proizvoda ili usluga koje će zadovoljiti njegovu potrebu među ustanovljenim alternativama.

- Ponašanje nakon kupnje: potrošač vrednuje proizvod ili uslugu nakon izvršene kupnje i korištenja što će ga potaknuti na određene naknadne akcije.

Budući da odluka o nastavku visokoškolskog obrazovanja spada pod složeno odlučivanje, predloženi model je primjenjiv i u tom kontekstu. Stoga je proces donošenja odluke generalno moguće opisati kako slijedi: faza ponašanja prije uključenja, prilikom koje potencijalni student pasivno razmišlja o odluci daljnjeg obrazovanja, faza ponašanja aktivnog uključenja, u kojoj student stvara listu potencijalnih izbora (institucija), faza podnošenja zahtjeva, u sklopu koje student prilaže zahtjev instituciji izbora, i faza ponašanja nakon prihvaćanja zahtjeva, kada student procjenjuje je li donio ispravnu odluku ili ne (Maringe i Carter, 2007).

Na temelju prikazanog modela može se zaključiti da ukoliko postoje alternativna rješenja potrošač će vrednovati dostupne alternative prije izbora. Dakle, ako se potrošaču ponude alternativna rješenja, tada on bira. Pitanje koje se postavlja jest na temelju kojih kriterija potrošač bira? Konceptom segmentacije tržišta može se doći do odgovora na to pitanje. 
Segmentacija tržišta može se definirati kao proces podjele tržišta na tržišne segmente odnosno skupine potrošača koji imaju iste ili slične potrebe (McDonald, 2004). Postoji više kriterija pri segmentiranju tržišta poput: zemljopisnih, demografskih, psihografskih i bihevioralnih (Kotler, 2001). Međutim, unutar bihevioralnih kriterija segmentiranja, kriterij koristi predstavlja snažan oblik segmentacije, a temelji se na identifikaciji koristi koje kupci očekuju od proizvoda ili usluge (Kotler, 2001). Segmentacija prema koristima predstavlja najkorisniji i najpraktičniji način da se objasni ponašanje potrošača (McDonald, 2004). Može se zaključiti da potrošači biraju na temelju vrijednosti koje se mogu protumačiti kao percipirane koristi koje pružaju pojedina alternativna rješenja na tržištu. Potrošač će odabrati onaj proizvod ili uslugu koja pruža najveće percipirane koristi u odnosu na dostupne alternative.

\section{Metodologija}

\subsection{Instrument istraživanja i uzorak}

Za potrebe segmentiranja tržišta visokog obrazovanja kreiran je anketni upitnik sastavljen od sedam pitanja, od kojih su pet zatvorenog, a dva otvorenog tipa. Traženi podaci su sljedeći: spol, dob, mjesto boravka i studiranja, razina studija i naziv upisane visokoškolske institucije, upisani smjer te koristi pri upisu institucije i smjera. Traženo je od ispitanika da na ponuđenoj listi od 23 koristi odaberu tri najznačajnije te da ih rangiraju po značaju. Anketni upitnik poslan je na 57 e-mail adresa visokoškolskih institucija u Hrvatskoj kako bi se proslijedila studentima na ispunjavanje. Istraživanje je provedeno od 11. rujna 2020. do 18. rujna 2020.

Analiza podataka vršena je pomoću programa MS Excel, dok je grupiranje ispitanika u segmente izvršeno web alatom za grupiranje podataka Wessa Free Statistics Software (Wessa, 2020).

Empirijskim istraživanjem obuhvaćena je populacija studenata na preddiplomskoj i diplomskoj razini u opsegu od 50 ispitanika. Bitno je naglasiti da odaziv nije bio velik te da veličina uzorka nije dovoljna za stjecanje realne slike tržišta. Stoga se ovo istraživanje može prihvatiti kao pilot studija i može poslužiti kao jedan opći pregled stanja na tržištu, a za dobivanje relevantnih podataka nužno je provesti istraživanje na većem broju ispitanika.

\subsection{Hipoteza}

U ovome radu postavljena je hipoteza da je na tržištu visokog obrazovanja moguće utvrditi između 5 i 10 jedinstvenih i međusobno različitih tržišnih segmenata. Bitno je napomenuti da za potrebe efikasnog i racionalnog poslovanja nije moguće upravljati velikim brojem segmenata, stoga je realna opcija utvrditi 5 do 10 tržišnih segmenata, jer je većina tržišta tako i podijeljena (McDonald i Dunbar, 2012). 


\section{Analiza podataka}

\subsection{Opći podaci}

U nastavku je dan opći pregled podataka provedenog istraživanja. Naglasak je stavljen na utvrđene koristi i njihovu zastupljenost te odnos između koristi i općih pokazatelja kao što su dob, spol, razina studija, smjer i područje studija.

Za potrebe istraživanja identificirano je 23 jedinstvenih koristi (Učeta, 2020) koje su potom grupirane kako bi se moglo pristupiti postupku segmentacije tržišta, jer velik broj varijabli nije pogodan za provođenje procesa segmentacije i realno utvrđivanje segmenata. Proces segmentacije tržišta proveden je na temelju pet utvrđenih grupa koristi.

Tablica 1. Grupirane identificirane koristi

\begin{tabular}{|c|c|c|}
\hline & Korist & Grupirane koristi \\
\hline 1 & Širi spektar zapošljavanja & \multirow{6}{*}{ Materijalne i profesionalne koristi } \\
\hline 2 & Dobro plaćen posao & \\
\hline 3 & Lakše zapošljavanje & \\
\hline 4 & Lakša prilagodba poslu & \\
\hline 5 & Siguran i stabilan posao & \\
\hline 6 & Poslovna nezavisnost (sam svoj šef) & \\
\hline 7 & Ušteda novca & Financijske koristi \\
\hline 8 & Društvena i moralna podrška & \multirow{5}{*}{ Društvene koristi } \\
\hline 9 & Kvaliteta društvenog života & \\
\hline 10 & Promicanje etičkih i društvenih vrijednosti & \\
\hline 11 & Stjecanje multikulturalnih socijalnih vještina & \\
\hline 12 & Stjecanje statusa u društvu & \\
\hline 13 & Osobno zadovoljstvo & \multirow{7}{*}{ Osobne koristi } \\
\hline 14 & Osobno usavršavanje & \\
\hline 15 & Osamostaljenje & \\
\hline 16 & Kvaliteta života & \\
\hline 17 & Bolja životna perspektiva & \\
\hline 18 & Razonoda & \\
\hline 19 & Avanturistički život & \\
\hline 20 & Dostupnost studiranja & \multirow{4}{*}{ Institucijske koristi } \\
\hline 21 & Olakšan odabir institucije & \\
\hline 22 & Kvaliteta studiranja & \\
\hline 23 & Ušteda vremena studiranja & \\
\hline
\end{tabular}

Izvor: prilagođeno prema Učeta, M. (2020.), Segmentacija tržišta visokog obrazovanja (završni rad), Istarsko veleučilište - Università Istriana di scienze applicate, Pula

Tablica 1 prikazuje identificirane koristi i njihovu pripadnost u pet postavljenih grupa koristi: materijalne i profesionalne, financijske, društvene, osobne i institucijske koristi. Koristi su grupirane prema sličnosti tako da su, primjerice, u grupu materijalnih i profesionalnih 
koristi uvrštene sve koristi koje su direktno povezane s profesionalnim napretkom ali i stjecanjem prihoda, što je u izravnoj vezi s radnim mjestom i vrstom posla.

Za potrebe analize podataka te u cilju jasnijeg prikaza raspona značaja, pojedine koristi zamijenjene su vrijednošću odgovora na pitanje „Navedite tri glavna razloga (koristi) koja su vas potakla na odabir institucije i smjera studiranja". Sukladno tome, vrijednost 1 (najznačajniji čimbenik) pretvorena je u vrijednost 50, vrijednost 2 u 30, a vrijednost 3 (najmanje značajan čimbenik od 3 navedena) u vrijednost 10. Primjerice, kod ispitanika koji je odgovorio da mu je prvi kriterij po značaju dostupnost studiranja, a drugi kvaliteta studiranja, ova dva kriterija su zbrojena: $50+30=80$. Vrijednost 80 uvrštena je pod grupu Institucijske koristi, budući da oba čimbenika spadaju u tu grupu (Učeta, 2020). Na temelju toga dobiven je novi raspored vrijednosti koji je potom primijenjen za sve analize u nastavku, a posebno za postupak definiranja tržišnih segmenata.

Tablica 2. Zastupljenost koristi na cijelom uzorku

\begin{tabular}{|l|c|c|}
\hline Grupe koristi & Udio & Rang \\
\hline Materijalne i profesionalne koristi & $32 \%$ & 2 \\
\hline Financijske koristi & $0 \%$ & 5 \\
\hline Društvene koristi & $8 \%$ & 3 \\
\hline Osobne koristi & $53 \%$ & 1 \\
\hline Institucijske koristi & $7 \%$ & 4 \\
\hline & $100 \%$ & \\
\hline
\end{tabular}

Izvor: autori

U tablici 2 navedeni su rezultati analize gdje je moguće vidjeti zastupljenost odnosno ocjenu koristi na cijelom uzorku. Vidljivo je da osobne koristi dominiraju kao motivirajući čimbenici pri odabiru institucije visokog obrazovanja i smjera studiranja, i to s 53\%. To znači da studente u najvećoj mjeri motivira osobni napredak, primjerice, percepcija bolje životne perspektive, stjecanje osobnog zadovoljstva i usavršavanje. Drugi po značaju motivirajući čimbenici spadaju pod materijale i profesionalne koristi, dakle, osiguranje egzistencije kroz bolji posao i veće prihode. Ono što je indikativno jest to da nitko od ispitanika nije naveo financijske koristi (ili ušteda novca) kao značajan motivator, gdje primarno spada cijena školarine ali i ostali troškovi školovanja. Dakle, cijena školarine, bila ona visoka ili niska, nije utjecala na izbor institucije visokog obrazovanja i smjera studiranja. Društvene i institucijske koristi zastupljene su podjednako, u manjoj mjeri.

Tablica 3. Raspored koristi po spolu

\begin{tabular}{|l|c|c|c|c|c|}
\hline Spol & $\begin{array}{c}\text { Materijalne i } \\
\text { profesionalne } \\
\text { koristi }\end{array}$ & $\begin{array}{c}\text { Financijske } \\
\text { koristi }\end{array}$ & $\begin{array}{c}\text { Društvene } \\
\text { koristi }\end{array}$ & $\begin{array}{c}\text { Osobne } \\
\text { koristi }\end{array}$ & $\begin{array}{c}\text { Institucijske } \\
\text { koristi }\end{array}$ \\
\hline$M$ & $34 \%$ & $0 \%$ & $9 \%$ & $51 \%$ & $6 \%$ \\
\hline$\check{Z}$ & $31 \%$ & $0 \%$ & $8 \%$ & $54 \%$ & $8 \%$ \\
\hline
\end{tabular}

Izvor: autori 
Slika 3. Raspored koristi po spolu

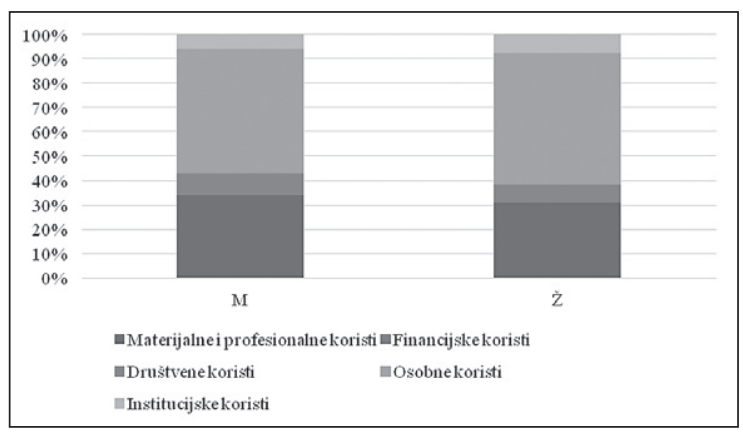

Izvor: autori

Tablica 3 prikazuje raspored grupa koristi prema spolu ispitanika. Unatoč biološkoj razlici među spolovima moglo bi se zaključiti da postoje razlike i u motivirajućim čimbenicima pri izboru institucije visokog obrazovanja i smjera studiranja. Međutim, generalno sagledavajući cjelovit uzorak nema bitnih odstupanja u koristima među spolovima. Dakle, studenti i studentice podjednako su motivirani u procesu donošenja odluke, promatrajući omjer specifičnih koristi. Navedeni rezultati uklapaju se u postojeće studije gdje je utvrđeno da se muškarci i žene, unatoč biološkoj različitosti, uglavnom slažu po pitanju traženih vrijednosti, primjerice u kontekstu materijalnih i profesionalnih koristi (Pew Research Center, 2013). Slika 3 daje jasan vizualni pregled omjera koristi prema spolu.

Tablica 4. Raspored koristi po dobi

\begin{tabular}{|l|c|c|c|c|c|}
\hline Dob & $\begin{array}{c}\text { Materijalne i } \\
\text { profesionalne koristi }\end{array}$ & $\begin{array}{c}\text { Financijske } \\
\text { koristi }\end{array}$ & $\begin{array}{c}\text { Društvene } \\
\text { koristi }\end{array}$ & $\begin{array}{c}\text { Osobne } \\
\text { koristi }\end{array}$ & $\begin{array}{c}\text { Institucijske } \\
\text { koristi }\end{array}$ \\
\hline $18-24$ & $22 \%$ & $0 \%$ & $8 \%$ & $61 \%$ & $9 \%$ \\
\hline $25-29$ & $48 \%$ & $0 \%$ & $11 \%$ & $39 \%$ & $2 \%$ \\
\hline $30-39$ & $62 \%$ & $0 \%$ & $0 \%$ & $36 \%$ & $2 \%$ \\
\hline
\end{tabular}

Izvor: autori

Slika 4. Raspored koristi po dobi

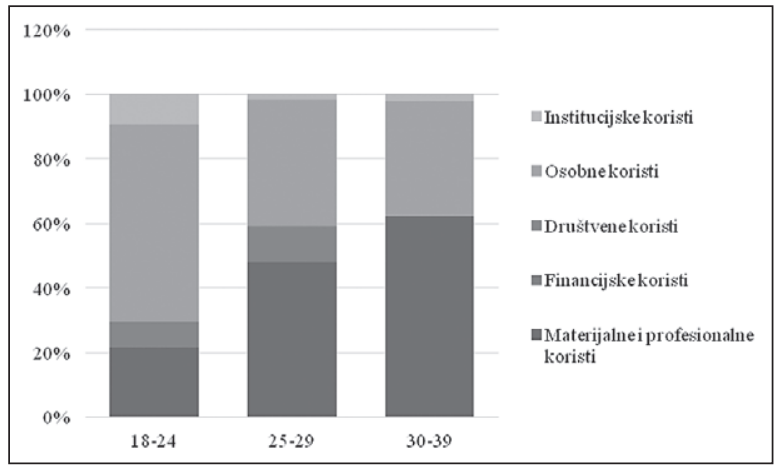

Izvor: autori 
Tablica 4 stavlja u odnos grupe koristi i dob ispitanika. Vidljivo je da osobne i profesionalne koristi dominiraju, kao što je utvrđeno u Tablici 2; međutim, njihov odnos varira s obzirom na razlike u dobnim skupinama. Što su ispitanici stariji, raste značaj materijalnih i profesionalnih koristi, a što su ispitanici mlađi, raste vrijednost osobnih koristi. Pretpostavka jest da stariji ispitanici spadaju u kategoriju izvanrednih studenata koji se susreću s realnim okolnostima u životu i imaju više životnog iskustva pa je osiguravanje materijalne egzistencije primarni motivirajući čimbenik pri odluci i odabiru institucije i smjera studiranja. Dakle, oni studiraju iz praktičnih razloga, što znači bolje radno mjesto, bolje plaćeno radno mjesto i slično. Slika 4 daje vizualni prikaz omjera grupe koristi po dobi ispitanika.

Tablica 5. Raspored koristi po razini studija

\begin{tabular}{|l|c|c|c|c|c|}
\hline Razina studija & $\begin{array}{c}\text { Materijalne i } \\
\text { profesionalne } \\
\text { koristi }\end{array}$ & $\begin{array}{c}\text { Financijske } \\
\text { koristi }\end{array}$ & $\begin{array}{c}\text { Društvene } \\
\text { koristi }\end{array}$ & $\begin{array}{c}\text { Osobne } \\
\text { koristi }\end{array}$ & $\begin{array}{c}\text { Institucijske } \\
\text { koristi }\end{array}$ \\
\hline Preddiplomska & $25 \%$ & $0 \%$ & $5 \%$ & $58 \%$ & $13 \%$ \\
\hline Diplomska & $37 \%$ & $0 \%$ & $10 \%$ & $50 \%$ & $3 \%$ \\
\hline
\end{tabular}

Izvor: autori

Slika 5. Raspored koristi po razini studija

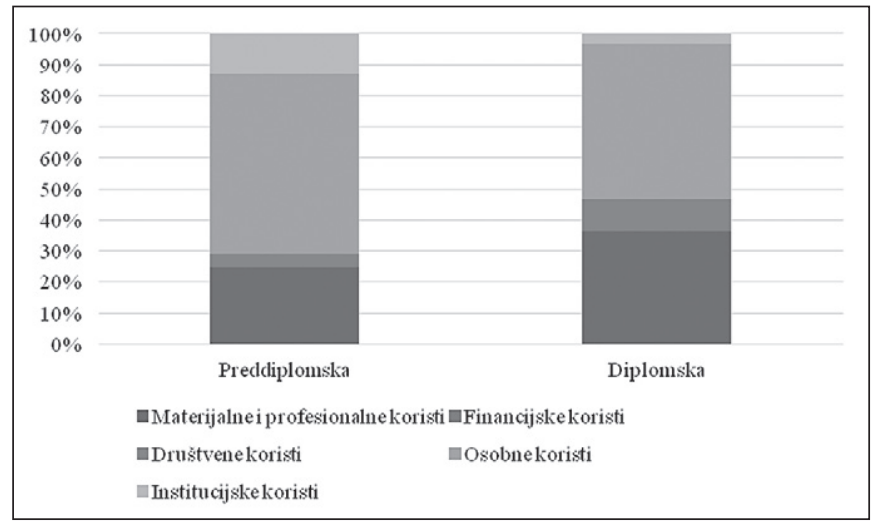

Izvor: autori

Tablica 5 stavlja u odnos grupe koristi i razinu studija ispitanika. Vidljivo je da na preddiplomskoj razini imamo manji udio materijalnih i profesionalnih koristi i veći udio osobnih koristi u odnosu na diplomsku razinu. Odstupanja su minorna, ali može se pretpostaviti da su na diplomskoj razini ispitanici nešto više motivirani osiguravanjem materijalne egzistencije pri odluci i odabiru institucije i smjera studiranja. S druge strane, osobne koristi dominiraju gotovo u podjednakoj mjeri među razinama studija. Slika 5 daje vizualni prikaz omjera grupe koristi po razini studija. 
Tablica 6. Raspored koristi po smjeru studija

\begin{tabular}{|l|c|c|c|c|c|c|}
\hline Smjer studija & $\begin{array}{c}\text { Broj } \\
\text { ispitanika }\end{array}$ & $\begin{array}{c}\text { Materijalne i } \\
\text { profesionalne } \\
\text { koristi }\end{array}$ & $\begin{array}{c}\text { Financijske } \\
\text { koristi }\end{array}$ & $\begin{array}{c}\text { Društvene } \\
\text { koristi }\end{array}$ & $\begin{array}{c}\text { Osobne } \\
\text { koristi }\end{array}$ & $\begin{array}{c}\text { Institucijske } \\
\text { koristi }\end{array}$ \\
\hline Medicina & 1 & $100 \%$ & $0 \%$ & $0 \%$ & $0 \%$ & $0 \%$ \\
\hline Ekonomija & 10 & $46 \%$ & $0 \%$ & $13 \%$ & $40 \%$ & $1 \%$ \\
\hline $\begin{array}{l}\text { Odgoj i } \\
\text { obrazovanje }\end{array}$ & 9 & $12 \%$ & $0 \%$ & $18 \%$ & $54 \%$ & $16 \%$ \\
\hline Biologija & 3 & $33 \%$ & $0 \%$ & $11 \%$ & $56 \%$ & $0 \%$ \\
\hline Fizika & 12 & $22 \%$ & $0 \%$ & $2 \%$ & $68 \%$ & $8 \%$ \\
\hline Matematika & 1 & $11 \%$ & $0 \%$ & $0 \%$ & $89 \%$ & $0 \%$ \\
\hline $\begin{array}{l}\text { Arhitektura i } \\
\text { urbanizam }\end{array}$ & 8 & $40 \%$ & $0 \%$ & $6 \%$ & $53 \%$ & $1 \%$ \\
\hline Mehatronika & 1 & $44 \%$ & $0 \%$ & $0 \%$ & $0 \%$ & $56 \%$ \\
\hline Politehnika & 2 & $33 \%$ & $0 \%$ & $0 \%$ & $61 \%$ & $6 \%$ \\
\hline Računarstvo/IT & 1 & $33 \%$ & $0 \%$ & $11 \%$ & $56 \%$ & $0 \%$ \\
\hline $\begin{array}{l}\text { Tehnologija } \\
\text { prometa i } \\
\text { transport }\end{array}$ & 1 & $56 \%$ & $0 \%$ & $0 \%$ & $33 \%$ & $11 \%$ \\
\hline Dizajn & 1 & $33 \%$ & $0 \%$ & $0 \%$ & $56 \%$ & $11 \%$ \\
\hline
\end{tabular}

Izvor: autori

Slika 6. Raspored koristi po smjeru studija

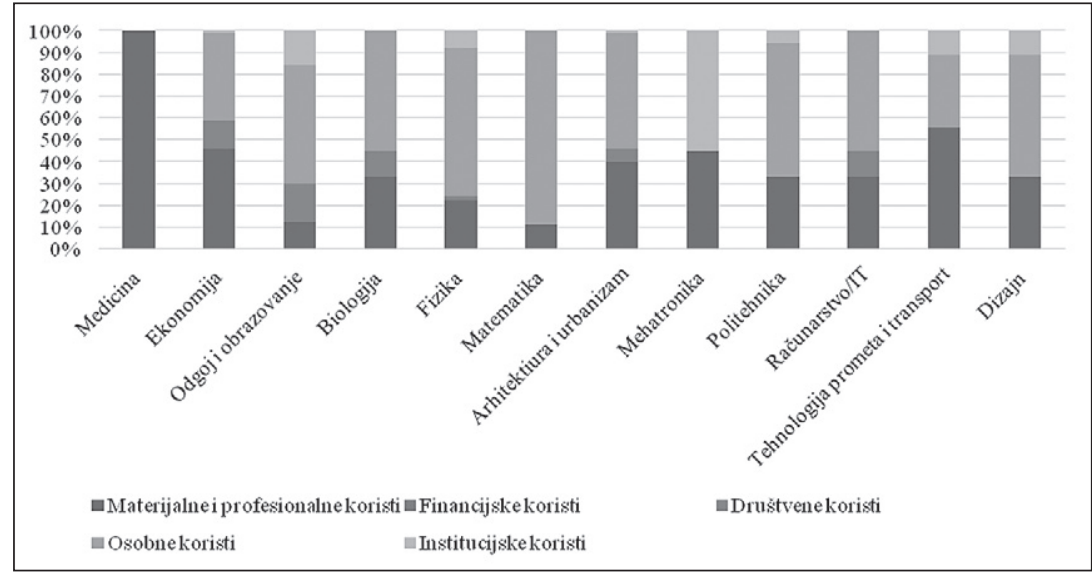

Izvor: autori

Tablica 6 i Slika 6 prikazuju raspored i omjere grupa koristi po smjeru studija. Prvenstveno treba biti oprezan i voditi računa o malom uzorku ispitanika; naime, za nekoliko smjerova zastupljen je samo jedan ispitanik, što ne može dati jasnu sliku stanja na tržištu visokog obrazovanja. Međutim, moguće je steći jednu opću sliku kretanja koristi s obzirom na specifične smjerove. Vidljivo je da medicina, tehnički smjerovi i ekonomija imaju veći udio materijalnih 
i profesionalnih koristi u odnosu na druge. Pretpostavka je da ta područja osiguravaju bolje uvjete što se tiče primanja i lakšeg zapošljavanja. Matematika, fizika i biologija imaju veći udio u osobnim koristima gdje osobno zadovoljstvo i osobni napredak predstavljaju bitniji motivator od materijalnih koristi.

Tablica 7 prikazuje raspored koristi po području studija na temelju čega je moguće dobiti jasniju sliku o motivirajućim čimbenicima pri odabiru institucije i smjera studiranja.

Tablica 7. Raspored koristi po području studija

\begin{tabular}{|l|c|c|c|c|c|c|}
\hline Područje & $\begin{array}{c}\text { Broj } \\
\text { ispitanika }\end{array}$ & $\begin{array}{c}\text { Materijalne i } \\
\text { profesionalne } \\
\text { koristi }\end{array}$ & $\begin{array}{c}\text { Financijske } \\
\text { koristi }\end{array}$ & $\begin{array}{c}\text { Društvene } \\
\text { koristi }\end{array}$ & $\begin{array}{c}\text { Osobne } \\
\text { koristi }\end{array}$ & $\begin{array}{c}\text { Institucijske } \\
\text { koristi }\end{array}$ \\
\hline $\begin{array}{l}\text { Biomedicina } \\
\text { i zdravstvo }\end{array}$ & 1 & $100 \%$ & $0 \%$ & $0 \%$ & $0 \%$ & $0 \%$ \\
\hline Društveno & 19 & $29 \%$ & $0 \%$ & $15 \%$ & $47 \%$ & $9 \%$ \\
\hline Prirodno & 16 & $22 \%$ & $0 \%$ & $4 \%$ & $71 \%$ & $2 \%$ \\
\hline Tehničko & 13 & $41 \%$ & $0 \%$ & $3 \%$ & $41 \%$ & $14 \%$ \\
\hline Umjetničko & 1 & $33 \%$ & $0 \%$ & $0 \%$ & $56 \%$ & $11 \%$ \\
\hline
\end{tabular}

Izvor: autori

Slika 7. Raspored koristi po području studija

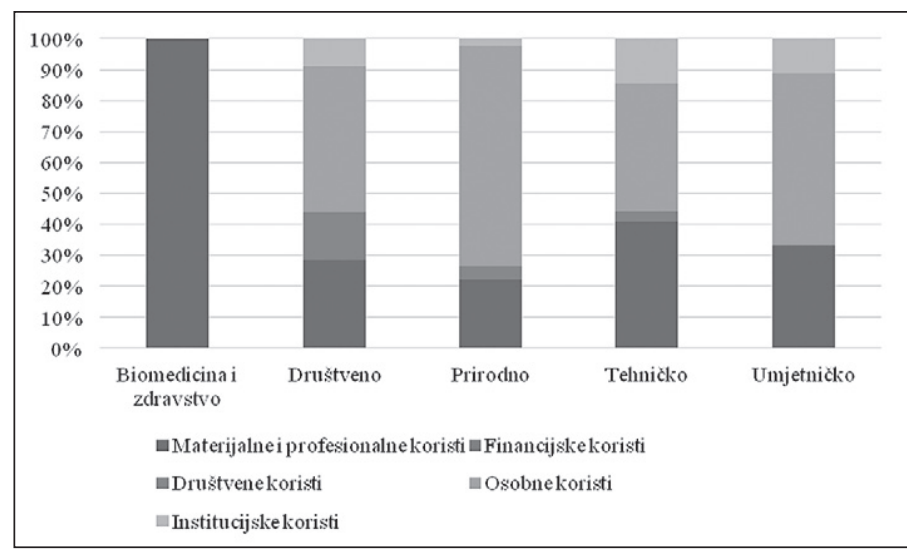

Izvor: autori

Tablica 7 i Slika 7 prikazuju raspored koristi po području studija, a dobivene su grupiranjem pojedinih smjerova studija iz Tablice 6 u pripadajuća znanstvena područja. Kao i u opisu prethodne tablice, pri interpretaciji rezultata treba voditi računa o malom uzorku ispitanika. Biomedicina i zdravstvo najdominantnija je u materijalnim i profesionalnim koristima, nakon čega slijedi tehničko područje. Pretpostavka je, kao što je ranije navedeno, da zanimanja u tim područjima donose više prihode, te studenti percipiraju da će završetkom tih studija steći veće materijalne i profesionalne koristi u tim profesijama. Što se tiče prirodnih znanosti, zastupljenost materijalnih i profesionalnih koristi je najmanja i pretpostavka 
je da studenti upisuju smjerove u tom području iz primarno iz drugih razloga, a ne zbog, primjerice, stjecanja većih prihoda. Osobne koristi najdominantnije su u prirodnom području te se pretpostavlja da su studenti pri odabiru takvih studija primarno vođeni osobnim preferencijama i zadovoljstvom prema tim studijskim programima. Bitno je istaknuti da su razlike u motivirajućim čimbenicima u pogledu traženih koristi pri odabiru institucije i smjera studiranja prema znanstvenim područjima vidno izražene, te je moguće generalno utvrditi profil potencijalnih studenata u pogledu njihovih osobnih interesa za studiranjem.

\subsection{Utvrđivanje tržišnih segmenata}

U nastavku su prikazani identificirani tržišni segmenti na tržištu visokog obrazovanja proizašli iz analize provedenog istraživanja. Tržišni segmenti kreirani su grupiranjem ispitanika prema iskazanim udjelima pojedinih koristi korištenjem alata za hijerarhijsko grupiranje Wessa Free Statistics Software (Wessa, 2020). Identificirano je 7 tržišnih segmenata.

Tablica 8. Veličina segmenata

\begin{tabular}{|l|c|c|c|c|c|c|c|}
\hline & S1 & S2 & S3 & S4 & S5 & S6 & S7 \\
\hline Broj & 7 & 5 & 14 & 11 & 8 & 3 & 2 \\
\hline Udio u ukupnom zbiru & $14 \%$ & $10 \%$ & $28 \%$ & $22 \%$ & $16 \%$ & $6 \%$ & $4 \%$ \\
\hline
\end{tabular}

Izvor: autori

Slika 8. Veličina segmenata

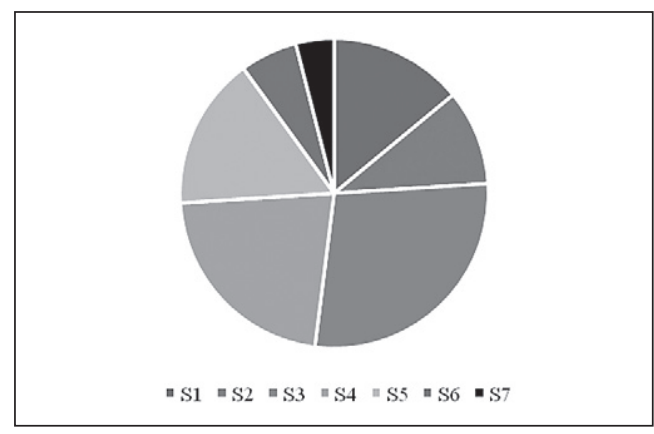

Izvor: autori

Tablica 8 i Slika 8 prikazuju veličine pojedinih segmenata s obzirom na cjelovit uzorak te je vidljivo da su najveći segmenti S3 i S4, s najviše ispitanika. Ujedno je vidljivo da određeni segmenti broje svega nekoliko ispitanika što ukazuje na ograničenje ovog istraživanja.

Utvrđeni tržišni segmenti na tržištu visokog obrazovanja prikazani su u Tablici 9. Identificirano je 7 tržišnih segmenata kreiranih grupiranjem ispitanika prema iskazanim udjelima pojedinih koristi. Udio koristi iz Tablice 9 izračunat je kao srednja vrijednost ocjena svih ispitanika u pojedinom segmentu za svaku grupu koristi zasebno. 
Tablica 9. Zastupljenost i udio koristi po segmentima

\begin{tabular}{|l|l|l|l|l|l|l|l|l|l|l|l|l|l|l|l|}
\cline { 2 - 14 } \multicolumn{1}{c|}{} & \multicolumn{2}{c|}{ S1 } & \multicolumn{2}{c|}{ S2 } & \multicolumn{2}{c|}{ S3 } & \multicolumn{2}{c|}{ S4 } & \multicolumn{2}{c|}{ S5 } & \multicolumn{2}{c|}{ S6 } & \multicolumn{2}{c|}{ S7 } \\
\hline $\begin{array}{l}\text { Grupe koristi } \\
\text { Udio }\end{array} \%$ & Udio & $\%$ & Udio & $\%$ & Udio & $\%$ & Udio & $\%$ & Udio & $\%$ & Udio & $\%$ \\
\hline $\begin{array}{l}\text { Materijalne i } \\
\text { profesionalne } \\
\text { koristi }\end{array}$ & 84 & $91 \%$ & 50 & $56 \%$ & 32 & $36 \%$ & 4 & $4 \%$ & 3 & $3 \%$ & 3 & $3 \%$ & 35 & $39 \%$ \\
\hline $\begin{array}{l}\text { Financijske } \\
\text { koristi }\end{array}$ & - & - & - & - & - & - & - & - & - & - & - & - & - & - \\
\hline $\begin{array}{l}\text { Društvene } \\
\text { koristi }\end{array}$ & - & - & 2 & $2 \%$ & 2 & $2 \%$ & 1 & $1 \%$ & 39 & $43 \%$ & 3 & $3 \%$ & - & - \\
\hline $\begin{array}{l}\text { Osobne } \\
\text { koristi }\end{array}$ & 8 & $9 \%$ & 32 & $36 \%$ & 54 & $60 \%$ & 83 & $91 \%$ & 46 & $51 \%$ & 50 & $56 \%$ & - & - \\
\hline $\begin{array}{l}\text { Institucijske } \\
\text { koristi }\end{array}$ & - & - & 6 & $7 \%$ & 2 & $2 \%$ & 3 & $3 \%$ & 3 & $3 \%$ & 33 & $37 \%$ & 55 & $61 \%$ \\
\hline
\end{tabular}

Izvor: prilagođeno prema Učeta, M. (2020.), Segmentacija tržišta visokog obrazovanja (završni rad), Istarsko veleučilište - Università Istriana di scienze applicate, Pula, str. 38-44

\section{Slika 9. Udio koristi po segmentima}

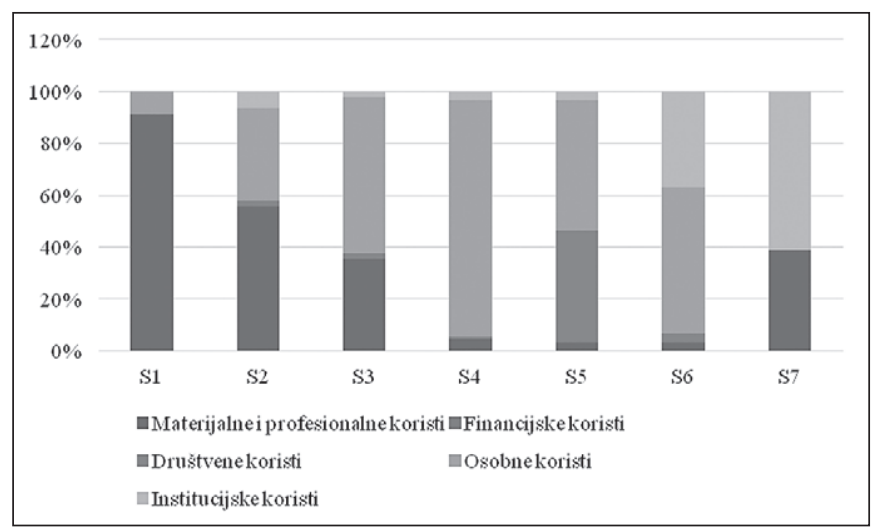

Izvor: autori

Tablica 9 i Slika 9 prikazuju omjere koristi što omogućava utvrđivanje razlika među segmentima, čime je moguće opisati segmente na tržištu visokog obrazovanja.

Segment 1: u segmentu dominiraju materijalne koristi s minornim udjelom osobnih koristi. Ostale koristi nisu zastupljene. Pretpostavka je da populacija u tom segmentu cilja primarno na one institucije i smjerove studiranja čija će im diploma nakon završetka studija osigurati stjecanje većih materijalnih koristi i bolje radno mjesto.

Segment 2: u segmentu dominiraju materijalne i osobne koristi. Ostale koristi su neznatno zastupljene. Pretpostavka je da će populacija u tom segmentu izbor bazirati primarno na one institucije i smjerove studiranja čija diploma osigurava materijalne koristi i bolje radno mjesto, ali su ujedno motivirani i osobnim koristima, važu izbor na temelju osobnih preferencija, traže veće osobno zadovoljstvo i osobna nadgradnja im je značajna. 
Segment 3: segment se značajno ne razlikuje od segmenta 2, s time da su ovdje vrijednosti najznačajnijih čimbenika obrnute. Naglašene i značajnije su osobne koristi u odnosu na materijalne koristi. Dakle, osobno zadovoljstvo sadržajem studiranja i osobna nadgradnja značajnija je od buduće materijalne perspektive pri donošenju odluke.

Segment 4: u segmentu dominiraju osobne koristi; drugim riječima, u ovu kategoriju spadaju studenti kod kojih su osobno zadovoljstvo u studiranju željenog smjera i bolja životna perspektiva presudni pri donošenju odluke. Utjecaj ostalih koristi poput materijalnih i institucijskih je minimalan.

Segment 5: u segmentu podjednako dominiraju dvije koristi, osobne i društvene. Pored naglašene želje za studiranjem željenog smjera, studenti su željni stjecanja socijalnih vještina, ali i društvene i moralne podrške od strane obitelji. Pretpostavka je da im je bitna blizina obitelji i prijatelja te nisu voljni seliti se daleko za potrebe studiranja.

Segment 6: segment se po omjeru vrijednosti ne razlikuje bitno od prethodnog segmenta, osim što su umjesto društvenih ovdje naglašene institucijske koristi. Želja za studiranjem željenog smjera i dalje je dominantna te za konačni odabir studenti važu opcije na temelju dostupnosti, blizine i kvalitete samog studija.

Segment 7: u segmentu dominiraju materijalne i institucijske koristi. Pri odabiru studentima je bitno da im stečena diploma osigura bolje radno mjesto i lakše zapošljavanje, ali pritom im je značajno da im je studij dostupan u blizini mjesta boravka. Pretpostavka je da se primarno radi o studentima uz rad koji za potrebe napredovanja na poslu trebaju višu stručnu spremu, ali zbog posla moraju studirati blizu mjesta boravka.

U Tablici 10 dan je detaljniji prikaz karakteristika ispitanika po segmentima, od demografskih pokazatelja, razine studija te upisanog smjera studiranja.

Iz priloženog je moguće dobiti jednu širu sliku o segmentaciji tržišta visokog obrazovanja, razlozima koji utječu na odabir institucije i smjera studiranja te smjerovima koji su zastupljeni odnosno koje studenti odabiru unutar svakog segmenta. Visokoškolske institucije mogu na temelju toga procijeniti na koje tržišne segmente ciljati, čime mogu efikasno planirati marketinške napore, ali i pretpostaviti potencijalni interes za vlastite studijske programe. 


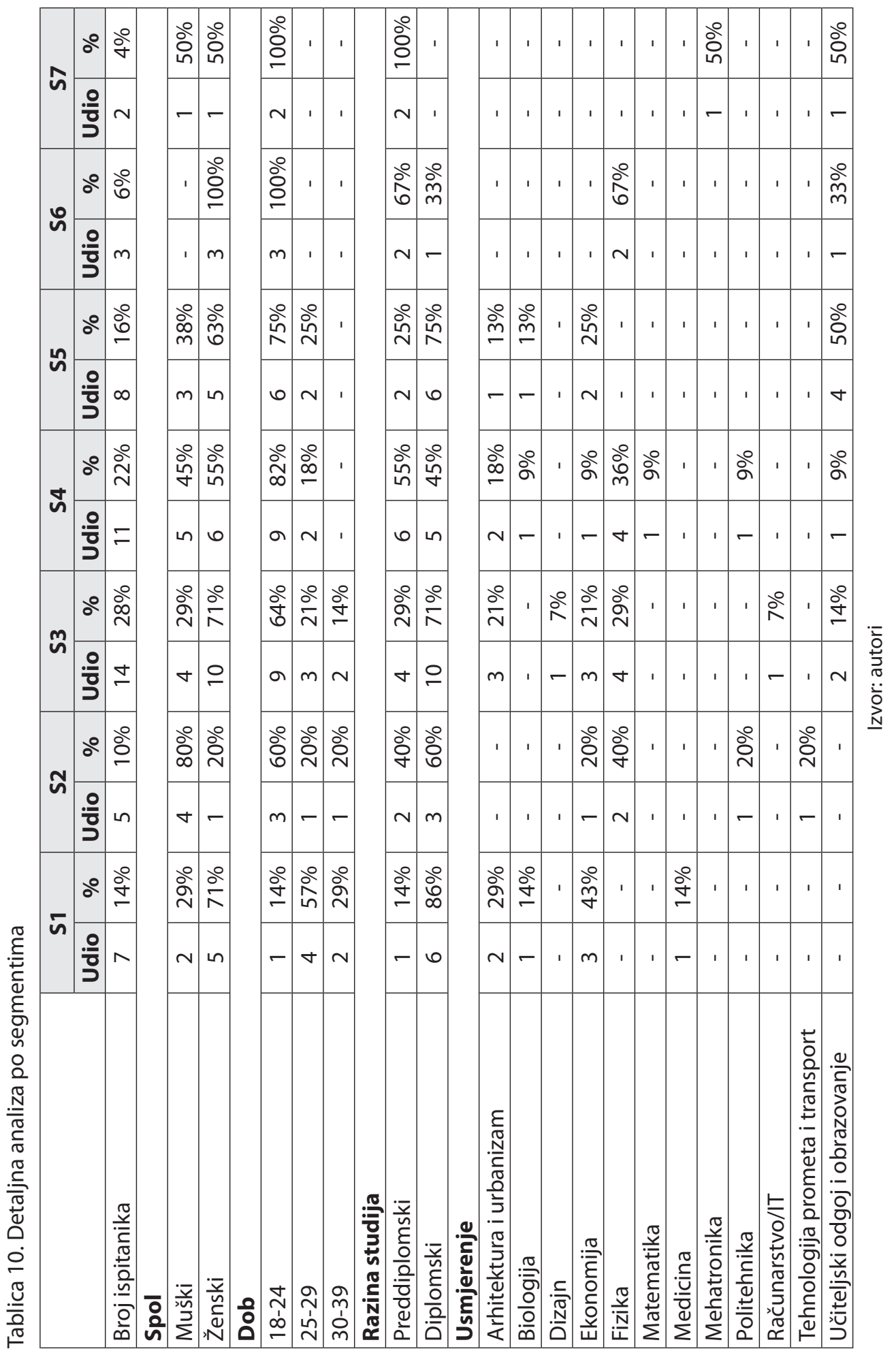




\section{Zaključak}

Jasno razumijevanje tržišta polazna je točka za marketinško planiranje. U situaciji kada potrošači imaju izbora, tada oni i biraju. Na tržištu visokog obrazovanja ima dovoljno izbora za potencijalne studente, što logički ukazuje na činjenicu da se tržište dijeli na segmente. Svaka visokoškolska institucija je specifična, a to se očituje kroz obrazovni sadržaj koji nudi na tržištu. Samim time nužnost je svake visokoškolske institucije da procijeni kakav joj je tržišni potencijal, na koje segmente može ciljati svojom ponudom i na koliki odaziv može računati. Pametnim planiranjem marketinških aktivnosti i efektnijom informacijom moguće je lakše doprijeti do potencijalnih studenata te istodobno racionalizirati marketinške napore i troškove.

Iz priložene analize utvrđeno je da na tržištu visokog obrazovanja postoji 7 jasno definiranih segmenata, što ulazi u postojeće okvire hipoteze. Time se, uvažavajući utvrđeno ograničenje istraživanja, može izjaviti da je hipoteza potvrđena. Provođenjem opsežnijeg istraživanja, što je preporuka autora, moguće je da će se u određenom stupnju promijeniti omjeri koristi i veličine pojedinih segmenata.

Rezultati ovog istraživanja, kao i onih dosad provedenih, ukazuju na jedan problem, a to je nepostojanje jedinstvenog pristupa za segmentiranje tržišta visokog obrazovanja. Različiti autori primjenjuju različite kriterije za segmentaciju, što u konačnici dovodi do značajnih razlika u rezultatima. Međutim, nipošto se ne želi ukazati na nevalidnost rezultata pojedinih istraživanja jer je proces donošenja odluke složen proces i postoji cijeli niz čimbenika koji na njega utječu. Stoga postoji potreba da se pojednostavi i unificira pristup za segmentaciju tržišta i utvrde najznačajniji čimbenici utjecaja koji će se potom koristiti kao temelj za segmentaciju.

\section{Ograničenja i preporuke za daljnja istraživanja}

Glavno ograničenje je veličina uzorka. Broj ispitanika nije dovoljno velik da bi se moglo preciznije procijeniti broj i značaj koristi za definiranje segmenata. To se posebice odnosi na one segmente sačinjene od svega nekoliko ispitanika. Iz navedenog proizlazi preporuka za provedbom istog istraživanja na većem uzorku ispitanika. Također, moguće je nadopuniti istraživanje podacima kao što su status studenta (redovni ili izvanredni), zaposlenost (jesu li studenti zaposleni ili nisu), kao i ostalim relevantnim podacima koji će moći dati kompletniju sliku tržišta visokog obrazovanja.

\section{LITERATURA}

1. Assael, H. (1998.), Consumer Behavior and Marketing Action, 6. edition, South-Western College Publishing, Cincinnati, Ohio

2. Church, J. H. i Gillingham, D. W. (1988). Benefit Segments for Full-Time Undergraduate Students. Canadian Journal of Higher Education, 18(2), str. 55-73

3. Hossler, D., Braxton, J., i Coopersmith, G. (1989.), Understanding student college choice, Higher education: Handbook of theory and research, 5, str. 231-288 
4. Kotler, P. (2001.), Upravljanje marketingom - analiza, planiranje, primjena i kontrola, 9. izdanje, MATE, Zagreb

5. Kotler, P., i Keller, K. L. (2006.). Marketing management, Prentice Hall, New Jersey

6. Leko Šimić, M., and Štimac, H. (2013.), Kvaliteta obrazovne usluge - slučaj Ekonomskog fakulteta u Osijeku. Ekonomsko obrazovanje u Republici Hrvatskoj - jučer, danas, sutra, Ekonomski fakulteti u Zarebu, Splitu, Rijeci, Osijeku, Puli i Dubrovniku, Zagreb, str. 249-262

7. Ladd, H., Reynolds, S. i Selingo, J. (2014). The differentiated university: Recognizing the diverse needs of today's students, The Parthenon Group, Boston, MA http://www.parthenon.com/ThoughtLeadership/TheDifferentiatedUniversity

8. Maringe, F., i Carter, S. (2007.), International students' motivations for studying in UK HE: Insights into the choice and decision making of African students. International Journal of Educational Management, 21(6), str. 459-475

9. Maringe, F., i Gibbs, P. (2009.), Marketing Higher Education - Theory and Practice, Open University Press, London

10. Marjanović, B. (2017.), Ponašanje potrošača u visokom obrazovanju - izbor obrazovne institucije na globaliziranom tržištu (doktorska disertacija), Sveučilište Josipa Jurja Strossmayera u Osijeku, Osijek

11. Mazzarol, T. (1998.), Critical success factors for international education marketing, International Journal of Educational Management, 12(4), str. 163-175

12. McDonald, M. (2004.), Marketinški planovi - kako ih pripremiti, kako ih koristiti, Zagreb: Masmedia

13. McDonald, M., i Dunbar, I. (2012.), Market segmentation: How to do it and how to profit from it, John Wiley \& Sons, West Sussex

14. Pardee, R. L. (1990.), Motivation Theories of Maslow, Herzberg, McGregor and McClelland, A Literature Review of Selected Theories Dealing with Job Satisfaction and Motivation

15. Patterson, P., Romm, T., i Hill, C. (1998.), Consumer satisfaction as a process: a qualitative, retrospective longitudinal study of overseas students in Australia, Journal of Professional Services Marketing, 16(1), str. 135-157

16. Pew Research Center. (2013.), On Pay Gap, Millennial Women Near Parity_For Now: Despite Gains, Many See Roadblocks Ahead, Pew Research Center, Washington, https://www. pewresearch.org/wp-content/uploads/sites/3/2013/12/gender-and-work_final.pdf (pristup: 15.12.2020.)

17. Schatzel, K., Callahan, T., Scott, C. J. i Davis, T. (2011). Reaching the non-traditional stopout population: a segmentation approach. Journal of Marketing for Higher Education, 21(1), str. 47-60

18. Shostack, L. G. (1982.), How to design a service, European Journal of Marketing, 16(1), str. 49-63

19. Sudarikov, A. E., Muratbakeev, E. K., Voronina, M. V., Tretyakova, Z. O. i Sudarikova, A. A. (2019). Higher education market segmentation. In International Conference "Topical Problems of Philology and Didactics: Interdisciplinary Approach in Humanities and Social Sciences" (TPHD 2018), Atlantis Press, str. 453-458

20. Učeta, M. (2020.), Segmentacija tržišta visokog obrazovanja (završni rad), Istarsko veleučilište - Università Istriana di scienze applicate, Pula 
21. Urednici Encyclopædia Britannica. (2009.), Higher education. Raspoloživo na: https:// www.britannica.com/topic/higher-education. (pristup: 26. 1. 2021.)

22. Wessa, P. (2020.), Free Statistics Software, Office for Research Development and Education, version 1.2.1, URL https://www.wessa.net/ (pristup: 21. 12. 2020.)

\section{Summary}

\section{HIGHER EDUCATION MARKET SEGMENTATION}

The paper analyzes the issue of identification of market segments in the higher education market. Segmentation is an important tool in achieving competitive advantage especially in mature and highly competitive markets. The higher education market is highly competitive especially in recent times when borders are open and student mobility is extremely accessible and easy to achieve. The market is open and every foreign higher education institution is a serious competitor to the domestic ones in the Republic of Croatia. This research established the existence of 7 specific market segments in the higher education market in Croatia based on one of the behavioral criteria, specifically on the benefit criterion. Based on the established factors, Croatian higher education institutions can adjust their own educational service with regard to the specifics of the targeted segments, which can give them an advantage over other competitors in the market.

Keywords: marketing in higher education, higher education services, benfit segmentation. 